\title{
Paideusis
}

\section{Building Communities in Philosophy of Education}

\section{Donald Cochrane}

Volume 19, Number 2, 2010

URI: https://id.erudit.org/iderudit/1071920ar

DOI: https://doi.org/10.7202/1071920ar

See table of contents

Publisher(s)

Canadian Philosophy of Education Society

ISSN

0838-4517 (print)

1916-0348 (digital)

Explore this journal

Cite this document

Cochrane, D. (2010). Building Communities in Philosophy of Education.

Paideusis, 19(2), 42-53. https://doi.org/10.7202/1071920ar

(c) Donald Cochrane, 2010

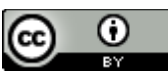

This document is protected by copyright law. Use of the services of Erudit (including reproduction) is subject to its terms and conditions, which can be viewed online.

https://apropos.erudit.org/en/users/policy-on-use/
This article is disseminated and preserved by Érudit.

Érudit is a non-profit inter-university consortium of the Université de Montréal, Université Laval, and the Université du Québec à Montréal. Its mission is to promote and disseminate research.

https://www.erudit.org/en/ 


\title{
Building Communities in Philosophy of Education
}

\author{
DONALD COCHRANE \\ University of Saskatchewan
}

You can take the boy out of the manse, but not the manse out of the boy. My father was a Presbyterian minister steeped in the writings of John Calvin and John Knox, several late nineteenth-century liberal German theologians, and the more contemporary neo-orthodox Swiss theologian, Karl Barth. In our family, a premium was placed on articulate speech, serious discussion, systematic thought, and religious belief. While an adolescent, I rebelled against all of those qualities at one time or another. Only now can I see that they had a profound, life-long influence on me.

At thirteen, I wanted to join my Sunday school compatriots who were trotting off to confirmation classes. Wisely, my father counseled me against taking this step because, he said, I was too young to fully understand what was involved. A year later, he asked me if I thought I was ready to join the church, but by that time serious doubts had arisen. ${ }^{1}$ Over the next several years, I read Schleiermacher, Bultmann, Bonhoeffer, Tillich, and J.A.T. Robinson and, while we talked about their ideas, my father never again asked about my beliefs. What remained from these discussions, however, was a serious concern about how one should live ones life.

In our home, dinner was served at precisely 6:00 p.m. For the first fifteen minutes, we listened to the $\mathrm{CBC}$ radio news after which vigorous conversation frequently ensued. My father held very firm views on many issues, but he did not dismiss contrary opinions a priori. As we lived in Montreal during the Duplessis era in the 1950s, political life was lively-rife with conflict and corruption. My father had lent modest support in the Roncarelli and Padlock $\mathrm{Law}^{3}$ cases, and when the Supreme Court ruled

\footnotetext{
${ }^{1}$ It was not until I was in Grade 12 that I discovered Matthew Arnold's (n.d., para 3) "Dover Beach," a poem that forcefully captured my sense of the loss of religious belief: "The Sea of Faith/Was once, too, at the full, and round earth's shore/...But now I only hear/Its melancholy, long, withdrawing roar,/Retreating, to the breath/Of the night-wind, down the vast edges drear/And naked shingles of the world.//Ah, love, let us be true/To one another! For the world, which seems/To lie before us like a land of dreams,/So various, so beautiful, so new,/Hath really neither joy, nor love, nor light,/Nor certitude, nor peace, nor help for pain;/And we are here as on a darkling plain/Swept with confused alarms of struggle and flight,/Where ignorant armies clash by night."

${ }^{2}$ Frank Roncarelli was a successful restaurant owner and practicing Jehovah's Witness in Montreal. Over three years, he furnished bail for over 375 Jehovah's Witness members, many of whom were arrested multiple times for distributing their literature without the proper permits under city by-laws. In 1946, at the behest of the city's chief prosecutor, Duplessis saw to it that Rocarelli's liquor license was revoked. He went broke in six months. Roncarelli v. Duplessis, [1959] S.C.R. 121 was a landmark constitutional decision of the Supreme Court of Canada in which it held that the premier had overstepped his authority. Duplessis died shortly after the verdict was delvivered.

3 The Padlock Act was a 1937 statute empowering the attorney general of Quebec to close any building for one year that had been used for propagating "communism or bolshevism" and to confiscate and destroy any printed matter propagating such views. Anyone printing, publishing, or distributing these materials could be imprisoned

(C) Copyright 2010. The author, Donald Cochrane, assigns to Paideusis the right of first publication and educational and non-profit institutions a non-exclusive license to use this document for personal use and in courses of instruction provided that the article is used in full and this copyright statement is reproduced. Any other usage is probibited without the express permission of the author.
} 
against Duplessis in both, there was much jubilation in our home. The election of the Liberal Party under Jean Lesage in 1960 was another occasion for great rejoicing.

Not all the topics around the table were "heavy" however. Sports-baseball, hockey, football, and boxing, in particular-were constantly subjects for discussion. The Montreal Royals were the tripleA farm team for the Brooklyn Dodgers, and so, most of their players came up through our franchise (Jackie Robinson went up to the majors from Montreal in 1947). As a result, we were die-hard Dodgers fans. The Montreal Canadiens were an obsession. Similarly, the fortunes of the Alouettes-particularly the play of Sam ("The Rifle") Etcheverry and Hal ("The Prince") Patterson-occupied our conversation.

My interest in boxing-which by a quirk of fate greatly influenced the course of my life-also came from my father. He would try to finish his sermon and the order of service before ten on Friday nights. He would return home promptly, put on the kettle for tea, and we would settle down to watch the Gillette-sponsored fight from Madison Square Gardens Some fifty years later, I can still find myself humming the theme for that program.

Though both of my parents were Queen's graduates (and Queen's graduates are extremely loyal!), it was assumed that I would attend McGill. Ministers have never been well paid and, and we could save a lot of money if I lived at home. As I knew that I wanted to teach high school and had fallen in love with English literature, I chose to honour in English and philosophy. While English was a "teachable" subject, I chose both areas for deeper reasons-they would allow me to explore the possibility of life being meaningful without the scaffolding of a religious faith.

McGill was a terrible place for undergraduate arts students in the late 1950s. All of my Westmount friends had joined fraternities and, as I had refused to be "rushed," I spent a lonely year. The student union on the corner of Peel and Sherbrooke was cramped and run down-hardly a place for forming new friendships. By the end of that year, I understood why fraternities at McGill were a necessary evil. With up to 100 students registered in my English classes, contact with our professors was limited to meetings twice a year for fifteen minutes to review our term papers. Despite similarly large enrolments, the year-long introduction to philosophy held in Redpath Hall was, for some reason, more successful. Thomas Henderson, head of the department, offered a sound, if uninspiring, survey of the pre-Socratics to Plato. The course really took off in the second semester when James W. Miller introduced us to Descartes, Hume, and James with wit, urbanity, and precision.

Boxing for McGill was a bright spot on my calendar. That year, the Canadian Intercollegiate Assaults (a.k.a. "championships") were held at Queen's. I sensed quickly during that weekend of competition that Queen's was where I belonged. On my return to Montreal, I told my parents that I would finish the year at McGill but that I would never again step foot on that campus as an undergraduate. I offered to work in the bush for a couple of years if that was what it would take. My parents were delighted, and although this decision meant some financial hardship for all of us, I was able to maintain our family tradition.

We used to say that Queen's was large enough to attract very good professors and small enough to allow us access to them. Among the most outstanding were A.R.C. Duncan, who taught a secondyear course in ethics and a two-term exploration of Kant's Critique of Pure Reason and George Whalley, who introduced us to the Romantics. My honours classes never exceeded more than twenty students. In the 1930s, the students had voted to ban fraternities from the campus - a policy that is still in place today. For me, the university was one large fraternity. Friends made during this time have remained friends for life.

After graduation in 1962, I took the one-year teacher training program at Bishop's University under the redoubtable Dr. Jeffrey Jefferis. He has been described as "a gifted teacher who was

for up to a year without appeal. Duplessis was both premier and attorney general. In 1957, the Supreme Court of Canada declared the Act unconstitutional ruling that the statute invaded the federal field of criminal law. 
unsparing in the demands he made on trainees." 4 Certainly, I was not among the spared! "Jeff" was the epitome of a teacher trainer, but he was not much of an educator. For reasons that were never made clear-perhaps because there weren't any-we were asked in our philosophy of education class to decide whether we were realists, idealists, or pragmatists. Though I did not know how, I was certain that there must be a better way for philosophy of education to contribute to the preparation of teachers.

In 1963, I moved to Vancouver to begin teaching. As the province would not recognize my teaching certificate from Bishop's, I applied and was hired by a private school that was modeled on the English public school. In fact, only two "masters", as we were called, had been born in Canada. School life was highly regimented, and the discipline was harsh. I was employed to teach English language and literature to students in grades 8 and 9. Paradoxically, though the school was very authoritarian, I had great freedom to create my own literature curriculum. My friends who were teaching in the public system envied the freedom I had. Among others, my students read poems by Lawrence Ferlinghetti, e.e. cumming, T.S. Eliot, Earle Burney, and Kenneth Fearing, and novels and short stories by Mordecai Richler, J.D. Salinger, and Malcolm Lowry. On Monday evenings, I instructed students on the basics of boxing, something that gave me a little more credibility as a teacher of poetry.

Though I was successful by most objective standards, I found that teaching some students who were "reluctant learners" was enervating. Every day after school, I would return home, pour myself a double rye and 7-Up, and sink into an armchair to read the Vancouver Sun. By the time I had finished the paper and downed my drink, my headache would have disappeared, and I could begin to think about marking papers for the evening. We did not have a word for it then, but I know now that I was "self-medicating". Had I continued to teach school for several years, I have no doubt that I would have become an alcoholic.

I loved teaching, and I missed philosophy. I thought I might be able to combine the two by studying philosophy of education with the hope that I could find a university position at the end of my studies. My first sense of the exciting developments at the Institute of Education University of London came from reading R.S. Peters' Authority, Responsibility, and Education (1959). So in the summer of 1965, I set sail for England on the S.S. Carmania to open a new chapter in my life.

\section{Institute of Education University of London}

When I arrived, the "London School of Philosophy of Education" was just getting off the ground. The team of Richard Peters, Paul Hirst, Robert Dearden, Pat and John White, and Ray Elliott was in place. We had a feeling that important discoveries were just about to be made. We were filled with a sense of anticipation, excitement, and seriousness of purpose.

In those early days, much emphasis was placed on the "logical geography of educational concepts" and the need to "map the territory". Clarity might not be enough, but greater clarity in much educational discourse was thought to be desirable. Critics thought that attention to the analysis of concepts was a sterile undertaking, but the "London School" hardly engaged in conceptual analysis for its own sake. ${ }^{5}$ Analysis for Peters was always in the service of some ethical issue. Epistemological concerns were Hirst's primary focus. For Elliott, it was the aesthetic. Not everyone embraced Continental philosophers immediately ${ }^{6}$, but traffic across the English Channel in both directions gradually increased.

\footnotetext{
${ }^{4}$ Christopher Nicholl, Bishop's University 1843-1970. Montréal: McGill-Queen's University Press, 1994. 290.

${ }^{5}$ For an interesting and extensive discussion of this period in philosophy of education, see Paul Standish. "Rival conceptions of the philosophy of education." Ethics and Education 2.2 (2007): 159-171, and a reply by John White. "Elusive rivalry? Conceptions of the philosophy of education." Ethics and Education 5.2 (2010): 135-145.

${ }^{6}$ Plato, Aristotle, and Kant had long been granted honorary British citizenship.
} 
In my first year, John White offered a lecture on the concept of creativity. After thirty-five minutes of a one-hour lecture period, we were surprised when he concluded by saying "That is as far as I have been able to take my thinking." He was not given to padding! By the next year, he had applied his analysis to the work of Torrance and Guilford and, as a result, needed the full hour. ${ }^{7}$ Peters lectured on education as initiation, the justification of worthwhile curriculum activities, respect for persons, and the concepts of equality, freedom, authority, and punishment. One week before our exam, his Ethics and Education (1966) was published. We rushed off to Dillon's Bookshop to purchase copies. Our cram book had arrived just in time.

The faculty worked incredibly hard on their writing, preparing lectures, commenting on our papers, and leading seminars. A similar intensity and dedication was expected from us. To read a paper in one of our seminars was a high-wire enterprise without much of a safety net. Criticism of our work was never personal but always thorough. The risk-taking was exhilarating, especially if we landed on our feet. We assimilated our professors' high standards and incorporated them into our own lives and careers.

London in the late 1960s was a swinging city, but it was also a vibrant cultural centre for the arts. In those days, students who lived on a very tight budget still had access to high culture. Standing room at the Proms and seats in the last rows of Festival Hall and Covent Gardens could be bought for $\$ 1.20$ to $\$ 2.40$ (12 shillings in the old currency). At those prices, we were able to attend performances by many of the world's best dancers, ${ }^{8}$ actors, ${ }^{9}$ conductors, ${ }^{10}$ and view art exhibitions of the century's finest artists. Entrance to the Tate Gallery and the National Gallery was free. At that time, the Courtauld Gallery was only two blocks from the Institute, and so, I spent many noon hours looking at a wall of seven unsurpassed Cezannes. It was also a time of political turmoil inside universities and on the streets. The last page of Time Out was entitled "Pick Your Demo." Here readers could find a list of demonstrations against apartheid, the war in Biafra, American involvement in Vietnam, or a cause of their choice. I helped myself generously to this section.

My five years in London was a time of great intellectual and cultural growth and laid the groundwork for my career.

\section{California State University, Northridge, Los Angeles}

In 1970, I was thirty and to that point I had only had to work full-time for two years. I was pleased that I had managed to be a student for what I thought might well be the first half of my life. It was time to find a permanent, full-time position. Fortunately, the head of the Department of Social and Philosophical Foundations at California State University Northridge (CSUN) had written to Peters to advise him of an opening in his department. I applied and was invited to visit the campus in April where I underwent a job interview that could only have taken place in southern California. It consisted of a walking tour of the campus and lunch with members of the department. I was not asked a single academic question. One member confided to me later that I had been deemed a "compatible personality" and with that the appointment proceeded.

While completing my time in London, President Nixon ordered the "incursion" into Cambodia. When news of this invasion became public, demonstrations erupted across the United States. Even on

\footnotetext{
7 This work was subsequently published as "Creativity and Education: A Philosophical Analysis" in the British Journal of Educational Studies 16.2 (1968): 123-37.

${ }^{8}$ For example, I was able to see Margot Fontaine and Rudolf Nureyev dance on five occasions.

${ }^{9}$ Including Paul Scofield, Ralph Richardson, Sybil Thorndike, Peggy Ashcroft, Claire Bloom, John Gielgud, and Lawrence Olivier.

10 Among them, Malcolm Sargant, Carlo Maria Giulini, Colin Davis, Herbert von Karajan, Otto Klemperer, and Leonard Bernstein.
} 
the other side of the Atlantic and without the benefit of CNN International, I learned of the disturbances and many arrests on the CSUN campus. I sensed that I would be living in interesting times in California. I was not disappointed.

On my first day in Los Angeles in August, 1970, I went straight to my university's administration offices to register my arrival. One of the forms I was required to sign was an oath not to take up arms against the government of the United States. After thinking about this for a moment, I asked the administrative assistant if I could add a phrase- "except where provided for by the Second Amendment." Apparently, no one had ever thought to protect the Constitution in this way. This minor crisis provoked a fairly lengthy, private discussion in the V-P's office and was resolved in a curious way. As I was not an American citizen, I did not have to sign this provision. Presumably, as Canadian citizen, I was free to bear arms against the state should it become unbearably oppressive, but I could not count on the support of my American colleagues. Thus my career at CSUN was launched.

Just before I arrived in Southern California, the psychopath Charles Manson was put on trial for the Tate-LaBianca murders and this story would be headline news for my first six months in Los Angeles. ${ }^{11}$ In February 1971, a major earthquake (6.6 on the Richter Scale) hit the region and, fearing the collapse of the Sylmar Dam, officials ordered the evacuation of 60,000 residents from the San Fernando Valley (I was among them) and the closing of our university for a week. Apart from the widespread damage it caused, the earthquake seemed symbolic of the social convulsions we were experiencing on campus and in the surrounding community. In 1973, Daniel Ellsberg and Tony Russo faced charges under the Espionage Act of 1917, including theft and conspiracy resulting from the publication of the "Pentagon Papers". ${ }^{12}$ Also in that year, I found myself in court testifying for three hours against the LAPD Riot Squad in a trial involving charges against two of our students who had been beaten during an on-campus demonstration against the war in Viet Nam. The surreal social and military madness of the times was never far away.

My department consisted of seven philosophers and five sociologists. Having spent five years in the philosophical hothouse at the Institute of Education, I expected discussions on educational theory to break out with frequency and intensity. They did not. Faculty members seemed more interested in "doing their own thing." As far as I could make out, this attitude was not restricted to my department but was prevalent across other departments in the School of Education. In brief, we did not have an academic community. If you hungered for scholarly engagement, you had to create it yourself. Thus, I invested heavily in my teaching, organized graduate student philosophy of education meetings, made contacts across campus with members of the philosophy department, and founded a state-wide association of philosophy of education.

I attended my first Far West Philosophy of Education Society conference in the fall of 1970, eager to meet colleagues from across the western states and to engage in philosophical discussion. It became apparent to me that one of the dominant purposes of the program was to generate as many CV entries per hour as possible, even though this format undermined serious philosophical exchange. My modest suggestions for reform were quietly ignored. After participating for three years, I left the "Far West" never to return. Clearly, I had been spoiled by my experience in London.

In frustration, I formed the California Association of Philosophy of Education (CAPE) in 1974. At our initial meeting, we decided to convene twice a year-once in the north of the state and once in the south. We always met on a campus because we wanted an academic, not a hotel, atmosphere. We billeted out-of-town guests in our homes-something that was initially thought of as a cost-cutting measure, but the bonding among members turned out to be the greatest benefit. We adopted the "London" program schedule: one paper Friday night followed by a social (called a "Rort" for reasons

\footnotetext{
${ }^{11}$ Apparently, I bore a strong resemblance to Manson, so much so that among my running friends I was known as "Charlie Boy."

${ }^{12} \mathrm{I}$ attended two days of the Ellsberg trial. It was eye-opening to watch the state organize its powerful resources to crush two dissenters.
} 
that in the mists of time are now obscure). Two papers were delivered on Saturday morning and one on Saturday afternoon. Membership was by invitation only.

Our by-laws revealed a contrary spirit at work. We agreed that, if our numbers ever reached thirty, the business meeting would automatically face a motion to divide the membership in two on grounds that good philosophy could not be done in a group larger than 30 ! Fortunately, membership leveled off at 28. If someone missed more than two consecutive meetings, the onus was on that member to justify his or her absence. We wanted to build an academic community, not maximize CV entries. CAPE succeeded in providing a workshop for papers-in-progress by subjecting them to supportive, critical consideration. ${ }^{13}$ Thirty-five years later, CAPE is still meeting despite the vicissitudes faced by our discipline in state universities and colleges. What is more, it has retained its original ideals. ${ }^{14}$

In the early 1970s, money abounded for moral education conferences, but it was clear to Lisa Kuhmerker, a professor and friend at Hunter College, New York, that these funds would soon run dry. She and I discussed how we might maintain momentum once austerity set in. We decided that I should found the California Association of Moral Education, and she would start a comparable organization on the East Coast. Ideally, we thought, the two regional outfits would meet in the fall, and we would try to establish an annual national conference in the spring. In between conferences in those pre-Internet days, we thought we needed a publication to keep everyone in touch with research and program developments. Thus, in 1975, the Moral Education Forum was born. My own role as the Associate Editor in the Forum's twenty-year existence was modest; Lisa's, as Editor, was huge. It was a privilege to work alongside Lisa - a person of enormous vision, energy, and commitment.

Our two fledgling moral education organizations started well, but after three years, it was clear that the eastern conference was quite naturally evolving into the national organization. In 1976, our two societies coalesced into what we now know as the Association for Moral Education (AME). Now in its thirty-fifth year, AME organizes an annual, high-level academic conference. Lisa's vision has been realized.

My greatest pedagogical pleasure during my ten years in California was the creation and teaching of a course entitled "Ethics in School Counselling." To introduce a new course that crossed into the "territory" of another department-in this case, educational psychology—was no simple matter. Indeed, most of the School's politics consisted of "turf wars" and these, in turn, were closely connected to the unspoken but omnipresent issue of preserving faculty positions. ${ }^{15}$ In 1973, California initiated a

\footnotetext{
13 At the 1975 Philosophy of Education Society Conference, three of the four open session papers had already been through the CAPE “workshop" process. See Donald Arnstine's “Apprenticeship as the Miseducation of Teachers" (113-123); Vince Crockenberg's "Politics as Education: The Foundation of the Morally Legitimate State" (280-93); and Donald Vandenberg's Education and the American Dream" (298-312) in Proceedings of the Thirty-First Annual Meetings of the Philosophy of Education Society, Kansas City, March 22-25, 1975. For a more personal testimonial, see Lynda Stone's "Drawing parts together-The philosophy of education of Nel Noddings", Utbildning \& Demokrati, 15. 1 (2006): 13-32: "In the interview, [Nel Noddings] describes presenting the first paper on caring in 1978 or 1979 before the California Association of Philosophy of Education (CAPE). CAPE is an intimate group of professors and their students who still meet twice yearly to give papers and offer criticism. She says, 'I thought...I'm really taking my chances here and I was a relative newcomer ... not only was it wellreceived . . . but I got so many letters and messages afterwards ... and that's when I started writing books.' "

${ }^{14}$ When I was appointed to a position at the University of Saskatchewan in 1980, I joined others in forming the Saskatchewan-Manitoba Association of Foundations of Education (SMAFE) that drew participants from the Universities of Saskatchewan, Regina, and Manitoba. The great distances between our institutions meant that our sense of isolation was considerable. We adopted the CAPE program format.

15 Budget cuts for education under Republican Governor Ronald Reagan (1967-1975) were severe. In the next round of elections, professors campaigned hard for Democratic Jerry Brown because they were led to believe that he would be more generous to the state university system. During Brown's tenure as governor (1975-1983), budget slashing continued.
} 
complete review of its credentialing programs. Everyone's job was up for grabs because the review panel had the power to mandate the content of all of these programs. This was both a frightening prospect and a challenging opportunity for a beleaguered department like my own. On February 8, 1974, I flew to Sacramento to present a brief before the Commission on Teacher Preparation and Licensing in which I argued in the five minutes allotted to me that a course on ethics and school counselling should be mandatory for all students in the state seeking a counselling credential. To my surprise, I was successful. I immediately set about to create such a course for our students and sent my detailed proposal to our educational psychology department. Again, to my surprise, members accepted it and were only too happy that I would relieve them of the burden of exploring the range of ethical issues. ${ }^{16}$ For my part, I saved my own job by creating work for myself and, thus, took some pressure off the department. I enjoyed the students in the program immensely and the subject matter proved fascinating for them and for me. ${ }^{17}$

Despite these efforts, the hold I had on my position remained tenuous. Given staffing formulas, the university was aiming to reduce the size of my department among others. The rumours that circulated in the fall of 1973 suggested that the president had about 50 names on a hit-list; then it was 25. I was on both lists. Then the administration noticed that 15 of the 25 were coming up for tenure that year. The administration played with the idea of denying tenure on "economic grounds." The state system had lay-off procedures that had some safe-guards for faculty built into them, but the Education Act in California had no provision for "economic lay-off." The president was inventing grounds for dismissal to help solve his financial problem. My union, United Professors California (UPC), fought vigorously against the president and was quite prepared to go to court on behalf of the "Northridge 15." Decisions on tenure had to be announced by May 28 of that year, the day of convocation. Earlier that week, I learned that I was to be awarded a Distinguished Teacher Award to be bestowed at convocation and I was invited to join the academic procession. I walked across campus that afternoon not knowing whether or not I had been laid off. In the president's office, I learned that the fifteen had been granted tenure, and so, the crisis had been averted.

But I was also under pressure from the federal government. Throughout my employment at CSUN, I had taught summer school in Canada at UBC, Queen's, and McGill. These stints allowed me to visit with friends and family, but also maintain academic contacts in the event that a position opened in Canada. I was employed at CSUN on what was called an H-1 Skilled Professional Visa which had to be renewed annually. The federal government introduced stricter immigration controls ostensibly to stem the tide of Mexicans from entering the country, but they had to be applied across the board. Employment preference was to be given to Americans. Should a qualified American be unemployed, the foreigner would be moved out of his or her position. No one could claim that there were no unemployed American philosophers of education. In 1975, while returning from teaching summer school at McGill, I was delayed twelve days in Vancouver waiting for my renewed visa to arrive at American customs. When it did, I rushed to the airport and boarded my flight. The hatch closed only to be opened again. I was pulled off the flight and questioned for twenty-five minutes. Other passengers simply had to wait. Eventually, I was allowed to board but advised to find a good lawyer as I would have to defend myself in immigration court within four weeks (and what a Star Chamber that was!). True to their word, I was summoned to a hearing and, although I granted a temporary reprieve, I was warned that I should not expect another renewal of my visa. The obvious way out of this predicament was to marry an American. That year, I had five proposals! But early in 1976, I met Nancy, and we decided together to marry for reasons of our own.

\footnotetext{
${ }^{16}$ I have no idea how other California state universities met this requirement.

${ }_{17}$ Many years later, John Schulte (a CSUN colleague who taught the course after I left the university in 1980) and I co-wrote Ethics in School Counselling. New York: Teachers College Press, 1995.
} 


\section{A Native Son Returns}

In 1980, I learned that the University of Saskatchewan was looking for a head of its Department of Educational Foundations. I applied and was appointed but, unlike CSUN, only after a series of very thorough interviews. I remain grateful for I have had a wonderful city in which my wife and I could raise our family; I could become a full-time member of my Canadian academic community; and I was able to settle into a positive academic environment in which to pursue my professional aspirations.

\section{The founding of Paideusis}

At the 1986 Canadian Society for the Study of Education (CSSE) conference held at the Universite de Montréal, a number of us in philosophy of education complained that we were limited to reading "foreign" journals and publishing "abroad" because we did not have an academic journal of our own. Did we lack the confidence to produce one ourselves? Some of us thought we had come of age and resolved to put the matter right—and soon. ${ }^{18}$

The next year at our Canadian Philosophy of Education Society (CPES) meeting at McMaster University, I presented a plan for a Canadian journal of philosophy of education. It would be produced by a team of two - an editor and a managing editor-and appear twice a year. The journal would be financed from members' dues and whatever library subscriptions we could hustle. Murray Elliott offered to write- very successfully as it turned out - to deans of education across Canada appealing for support to launch this new journal. (Some of our readers today may not be old enough to remember when deans actually had discretionary budgets.)

One of our colleagues worried that the costs of the journal could seriously erode our CPES funds to the point where they might result in the elimination of our free conference breakfast (our only other major society expense!). It was agreed that the journal would not cost more than three dollars per issue to produce. For twelve years, the journal stayed within budget and our "free" early morning breakfasts continued without interruption.

The most contentious issue was what to call our offspring. I proposed First Intuitions, Second Thoughts for which the acronym would be F.I.S.T. I had in mind a rather radical publication, something a little in-your-face, and featuring a few set pieces and much short commentary—sort of blogging before there was the technology to blog. Some worried about the connotations of "fist" in the verb form, and so, more conservative minds prevailed. Paul O'Leary proposed the journal be called Paideusis. I suspect that only he knew what it meant. No one else could even pronounce it, much less spell it (certainly not library subscription agents from Alabama, who would phone me as managing editor from time to time to ask after the whereabouts of a particular issue). For these reasons among others, Paul was appointed our first editor.

Our first issue appeared six months later in the fall of $1987 .{ }^{19}$ Have academics ever moved more quickly? The issue filled exactly 52 pages, a Procrustean bed imposed on us by Canada Post. That number of pages, the cover, and an envelope was the most we could mail and still stay within the lowest possible postage rate. One more sheet-four more pages—and members might miss their CPES conference breakfasts.

${ }^{18}$ With the similar concerns in mind, Martin Schiralli and I edited Philosophy of Education: Canadian Perspectives. Don Mills, ON: Collier-Macmillan Canada, 1982.

${ }^{19}$ It consisted of Robin Barrow's "Conceptual Finesse," Deanne Bogdan's “A Taxonomy of Responses and Respondents to Literature,” Jerrold Coombs "Respect for the Law: An Educational Objective?” and Cornel Hamm's review of Bill Hare's In Defence of Open-mindedness. 
I had the pleasure of serving as the managing editor for three wonderful editors-Paul O'Leary, Bill Hare, and John Portelli-from 1987 to 1999. We worked hard together for those twelve years and, as I look back on the first twenty-four issues, I think we can be proud of the start we made.

Having moved to an online version, the readership has greatly expanded and some of those early ideas about first intuitions and second thoughts are now being realized.

\section{So Much for the Mind}

Colleagues in other educational disciplines were often critical of the extent to which our papers and articles in the 1980s appeared to start and end in a rarified, conceptual stratosphere. We might be able to see the connection to practice, but many others did not. As well, our publications seldom contained any specifically Canadian content; we could just as well have been writing in the United States, Australia, or England. ${ }^{20}$ It was as if we were working in some kind of a global Platonic world of Ideas.

In 1981, the Saskatchewan Minister of Education called for a review of curriculum and instruction. Over a number of years, a committee of "stakeholders" crisscrossed the province holding public meetings and engaging in what they called "collaborative planning." Several of us sensed that something was amiss when the committee's first report was distressingly bereft of any reasons for the recommendations it contained. ${ }^{21}$ It seemed like a perfect opportunity for philosophers to engage in practical matters.

Three of us at the University of Saskatchewan and three at the University of Regina agreed to offer short papers as part of professional development in our faculties. I thought I might contribute a paper on the proper place for skills in directing public education (since "skills talk" pervaded the Directions report). In the course of preparing for this talk, I stumbled over an ASCD publication 22 in which its "Goals of Education" looked depressingly similar to those allegedly devised by our provincial committee and, by that time, posted on school notice boards all over the province. I delivered my paper under the title of "Taking our Directions from Washington." The press caught wind of possible plagiarism in high places, and soon the story appeared in local papers, and on television and radio. For about three years, I remained persona non grata in official circles, but the controversy stimulated some of my colleagues in our two provincial universities to examine more closely how the government and "educational stakeholders" were engaging in educational policy making. The discussions we had around these issues were the most stimulating I had in my twenty-five years at the University of Saskatchewan. The results were published in a book entitled So Much for the Mind. ${ }^{23}$

\section{Scrutiny}

Once So Much for the Mind had been published, and we had tasted the excitement of philosophy applied to practical matters, we were loath to walk away. With my colleagues Bob Regnier (University of

\footnotetext{
20 A notable exception is William Hare's "Limiting the Freedom of Expression: The Keegstra Case."Canadian Journal of Education, 15.4 (1990): 375-89.

21 See its first report entitled Directions. Regina, SK: Saskatchewan Education, 1984. Nadine Gordimer best captured our unease when she wrote, "When the State projects a social vision...it does so through the perceptions of planners, advisers, commissions, experts in this and that...spokesmen, politicians. The formation of the State's vision is a process of briefing. Its product is social engineering." See her "How Does the State Imagine?", PEN Congress, 1986.

22 See Wilbur B. Brookover et al., Measuring and Attaining the Goals of Education. Arlington, VA: Association for Supervision and Curriculum Development, 1980.

${ }_{23}$ Donald Cochrane, ed.. So Much for the Mind: A Case Study in Provincial Curriculum Development. Toronto: Kagan and Woo, 1987. The title is a play on Hilda Neatby's So Little for the Mind (1953). Dr. Neatby was a professor at the University of Saskatchewan and the head of its history department from 1958 to 1969.
} 
Saskatchewan) and Doug Stewart (University of Regina), we launched Scrutiny, a bulletin devoted to education in Saskatchewan. We promised to "celebrate excellence, scowl at the sloppy and superficial, expose the ridiculous, and harry the wicked." 24 For seven-and-a-half years, we did just that. Not surprisingly, we found more plagiarism, but in addition to those exposés, we published some good analyses of local educational issues. We ended publication of our bulletin not from a lack of interesting material but simply from exhaustion.

\section{Two books that corrected moral blindness}

When I reflect on my life, I am struck by how insensitive I have been to the mass killing of animals for sport, clothing, entertainment, research, and food. I have also been quite blind to the treatment of sexual minorities in our society. Of course, these issues were never discussed in any of the traditional philosophy classes I had taken, but they contained moral dimensions for those who had eyes to see them. . $^{25}$

Novalis's claim that "philosophy can bake no bread" 26 should not be taken as a blanket dismissal of the very practical consequences that often follow from its study. When we experience what Plato describes in the Myth of the Cave, our beliefs about what is good, true, and beautiful are so altered that our lives are irrevocably changed. Can one book do the trick? Tom Regan makes a modest claim for himself: “...while all writers hope their words have some power for the good, I would be fooling myself if I believed that my words alone might have the power to change how people see animals in the blink of an eye.... [] f my words can be of any possible use to anybody, it will be to people who are growing slowly into animal consciousness...."27 Regan accounts exactly for my own developing consciousness. I was ready for change and his work showed me the way.

Regan's The Case for Animal Rights ${ }^{28}$ had a profound effect on me. I had practiced vegetarianism for two or three years while in California but without a sound ethical basis, and in any case, the scope of my concern was limited to the issue of food. Regan's very careful philosophical argument and his concept of a "subject-of-a-life" deepened and broadened my commitment. I had been what Regan later called a "muddler":

Whatever the path taken, and however long it takes, "Muddlers" (as I call them) grow into animal consciousness step by step, little by little.... The transformation is noteworthy and, once it occurs, permanent. For Muddlers, a day finally dawns when we look in the mirror and, to our surprise, we see an Animal Rights Advocate looking back at us. ${ }^{29}$

After reading The Case for Animal Rights, the day finally dawned for me.

\footnotetext{
24 Scrutiny 1.1 (1990): 1.

25 I am embarrassed to acknowledge that my Ethics in School Counseling (New York: Teachers College Press) cowritten with John Schulte was published in 1995 without any mention of the crises faced by sexual minority students and teachers, and yet I was teaching a course entitled "Gay and Lesbian Issues in Education" in 1997. A significant transformation took place in the intervening two years, but I am unable to give a satisfactory account of the change even to myself.

${ }^{26}$ But then went on to add: “...but she can procure for us God, Freedom, Immortality. Which, then, is more practical, philosophy or economy?"

${ }^{27}$ Tom Regan, Empty Cages: Facing the Challenge of Animal Rights. New York: Rowman and Littlefield Publishers, Inc., 2004. 27.

28 Tom Regan, The Case for Animal Rights. Berkeley, CA: The University of California Press, 1983.

${ }^{29}$ Tom Regan, 2004, op. cit., 25-26.
} 
David A.J. Richards' his early work ${ }^{30}$ and his more recent The Case for Gay Rights: From Bowers to Lawrence and Beyond ${ }^{31}$ had a similar effect on my thinking and on my life. I had become concerned with sexual minority issues in my university and community just before Women, Gays, and the Constitution (1998) and Identity and the Case for Gay Rights (1999) were published. Richards writing did not cause a new consciousness to emerge but, as a "muddler" here as well, he provided the firm foundations I needed for my life-changing commitment.

\section{Two other courses that mattered}

I had always been remotely aware that sexual minorities faced severe discrimination in our education system and in society generally, but I had never been moved to any concerted action to oppose it. At the University of Saskatchewan, very few had broken the silence on the issue. No course had ever taken sexual orientation as its central focus. As well, I knew of no precedent in another faculty of education in Canada. Without a map to guide me, I decided I would create a course to explore sexual minority issues in education. Creating the course was an education in itself. Gaining approval for it in a faculty meeting was a tense affair. After a full debate in which several colleagues demurred, the course was approved. At the end of the meeting, supporters gathered to give one another hugs - the only time in my thirty-five-year university career that I have experienced such a response at a faculty meeting. That day, we knew we had done something good. ${ }^{32}$

When I taught the course for the first time in the fall of 1997, I urged my students to focus their research paper on a topic that would illuminate our situation in Saskatchewan. We knew much about reports, agencies, court cases, and so on in Boston, Vancouver, and Toronto, but we were largely ignorant of what was going on in our own province. One student undertook to interview three young people - two of whom had switched high schools to avoid harassment, and the third who had dropped out altogether. When I saw how excellent her first draft was, I said to her, "This is far too good to be written for an audience of one; we need to have a conference!" A year later guided by an extraordinary advisory committee, I founded the Breaking the Silence Conference. ${ }^{33}$ We are now preparing for the fifteenth annual conference.

I often referred to "Gay and Lesbian Issues in Education" as my "political course". My graduate "Education, Wisdom, and Nature" course was my "heart-and-soul" course. It allowed me to focus on preoccupations with which I had lived for most of my life. I had, as Toulmin put it, this ambition to talk about the "Universe as a Whole" which reflected "the need to recognize where we stand in the world into which we have been born, to grasp our place in the scheme of things, and to feel at home within it." 34 The Book of Job had convinced me that God was not in his heaven and all was not right with the world. Must we conclude with Lao Tzu that "heaven and earth are ruthless, and treat the myriad creatures as straw dogs" or is there a more positive way to look at our brief lives? My philosophical wanderings had brought me back to the manse and to the questions raised there so long ago.

\footnotetext{
${ }^{30}$ David A. J. Richards. Women, Gays, and the Constitution: The Grounds for Feminism and Gay Rights in Culture and Law. Chicago: University of Chicago Press, 1998; David A. J. Richards. Identity and the Case for Gay Rights: Race, Gender, Religion as Analogies. Chicago, IL: University of Chicago Press, 1999.

${ }^{31}$ David A. J. Richards. The Case for Gay Rights: From Bowers to Lawrence and Beyond. Lawrence, KA: University Press of Kansas, 2005.

32 An early version of this fourth-year elective course entitled "Gay and Lesbian Issues in Education" can be found at <http://www.usask.ca/education/coursework/edfdt486/index.htm $>$ in 1997.

33 The first Breaking the Silence Conference was held in $1998<\underline{\text { http://www.usask.ca/education/breaking-the- }}$ silence/index.htm $>$.

${ }^{34}$ Stephen Toulmin. The Return to Cosmology: Postmodern Science and the Theology of Nature. Berkeley: University of California Press, 1982. 1.
} 


\section{Retirement}

I reached the age of 65, after ten years at CSUN and twenty-five years at the University of Saskatchewan (with more than seventeen as a department head). Sugar Ray Robinson, one of my boxing heroes, once remarked, 'You always say 'I'll quit when I start to slide,' and then one morning you wake up and realize you've done slid." I wanted to retire before I "had done slid" and while I could still enjoy academic pursuits. I had imagined long hours of reading the "canon" and beyond. I have found the truth in Anthony Burgess's sly observation: "War and Peace must wait for the leisure of retirement, which never really comes; meanwhile, it helps furnish the living room." 35 My living room is well furnished.

\section{Works that have significantly influenced my thinking:}

Arnold, Matthew. "Dover Beach”. Matthew Arnold (1822-1888). Web. 15 June 2011. $<$ http://www.poemhunter.com/poem/dover-beach>

Dillard, Annie. For the Time Being. Toronto: Penguin, 1999.

Horowitz, David. From Yalta to Vietnam: American Foreign Policy in the Cold War. Harmondsworth, Middlesex: Penguin, 1967.

Kant, Immanuel. Critique of Pure Reason. London: Macmillan and Co., 1958.

Kant, Immanuel. Groundwork of the Metaphysics of Morals. New York: Harper Torchbooks, 1964.

Koestler, Arthur. The Sleepwalkers: A History of Man's Changing Vision of the Universe. Harmondsworth, Middlesex: Penguin Books, 1959.

Peters, Richard S. Ethics and Education. London: George Allen and Unwin, 1966.

Rawls, John. A Theory of Justice. Cambridge: Harvard University Press, 1971.

Regan, Tom. The Case for Animal Rights. Berkeley: University of California Press, 1983.

Richards, David A.J. Identity and the Case for Gay Rights: Race, Gender, Religion as Analogies. Chicago: University of Chicago Press, 1999.

Schweitzer, Albert. Albert Schweitzer: An Anthology. Edited by Charles R. Joy. Boston: Beacon Press, 1955.

The Bible (n.d.). The Books of Job and Ecclesiastes.

35 Anthony Burgess. You've Had Your Time. $1^{\text {st }}$ ed. London: William Heinemann Ltd.,1990. Ch. 2. 